\title{
Do academics and university administrators really know better? The ethics of positioning student perspectives in learning analytics
}

\author{
Deborah West \\ Flinders University
}

Ann Luzeckyj

Centre for Innovation in Learning and Teaching, Flinders University

Danny Toohey

School of Engineering and Information Technology, Murdoch University

Jessica Vanderlelie

Student Success, La Trobe University

\section{Bill Searle}

Charles Darwin University

\begin{abstract}
Increasingly learning analytics (LA) has begun utilising staff- and student-facing dashboards capturing visualisations to present data to support student success and improve learning and teaching. The use of LA is complex, multifaceted and raises many issues for consideration, including ethical and legal challenges, competing stakeholder views and implementation decisions. It is widely acknowledged that LA development requires input from various stakeholders. This conceptual article explores the LA literature to determine how student perspectives are positioned as dashboards and visualisations are developed. While the sector acknowledges the central role of students, as demonstrated here, much of the literature reflects an academic, teacher-centric or institutional view. This view reflects some of the key ethical concerns related to informed consent and the role of power translating to a somewhat paternalistic approach to students. We suggest that as students are the primary stakeholders - they should be consulted in the development and application of LA. An ethical approach to LA requires that we engage with our students in their learning and the systems and information that support that process rather than assuming we know we know what students want, what their concerns are or how they would like data presented.
\end{abstract}

Implications for practice or policy:

- Universities should actively engage with students to understand their concerns related to learning analytics.

- Universities should ensure that learning analytics dashboards are deployed in line with student requirements from their perspective.

- Institutions need to provide students and staff with training in the use of learning analytics.

- Universities should ensure that data is collected transparently and with students' knowledge and, where appropriate, informed consent.

Keywords: learning analytics, student perspectives, ethics, student concerns, data privacy

\section{Introduction}

This article explores the literature related to student perspectives on the development and use of learning analytics (LA) applications, visualisations and reports. LA, commonly defined as "the measurement, collection, analysis and reporting of data about learners and their contexts, for purposes of understanding and optimising learning and the environments in which it occurs" (Long \& Siemens, 2011, p. 34), has a variety of purposes and different target audiences. Purposes include the improvement of curriculum, improvement of teaching practice, more effective engagement in learning, retention and improved student success. At the heart of all of these applications is the student, who is both the primary stakeholder and for whom LA provides an added value, although there is distinct flow on to other stakeholders. Dollinger and 
Lodge (2018) challenge Long and Siemen's (2011) definition suggesting that in order for LA to achieve its full potential, it needs to be both aboiut as well as with learners and therefore include strategies which enable co-creation of learning to occur. In this article we support Dollinger and Lodge's (2018) critique arguing that much of the LA literature focuses on identifying measures and presentations that demonstrate what is occurring in relation to or about learners rather than what can be done or might occur with or alongside them.

Underlying LA is the use of increasing amounts of data and our ability to analyse this in more sophisticated and complex ways. However, for most stakeholders, such data must be presented in a way that is useful, insightful and actionable. This presentation generally takes the form of either a visualisation, report and/or dashboard. Schwendimann et al. (2016, p. 533) define a learning dashboard as "a single display that aggregates multiple visualizations of different indicators about learner(s), learning process(es) and /or learning context(s)". They report that when dashboards had been reviewed in the extant research, the focus was on the mechanics of the dashboard, particularly in terms of "usability, usefulness or user satisfaction" (p. 533) with little reference as to how the visualisations impacted learning. A number of authors (Bodily \& Verbert, 2017; Jivet, Scheffel, Drachsler, \& Specht, 2017; Jivet, Scheffel, Specht, \& Drachsler, 2018; Kitto, Lupton, Davis, \& Waters, 2016, 2017) identify the importance of placing students as central in both generating data and consuming outputs as work in relation to student dashboards progresses. Yet few discuss how they have determined what students want or how information on dashboards is accessed, interpreted and acted on by students.

After a brief introduction to the concept and work on reports and visualisations, this article explores the role of the student as the primary stakeholder in LA. As LA raises a variety of ethical considerations, particularly when the student is clearly identified as the primary stakeholder and which we agree is important, we highlight a number of the ethical concerns. Also, given our premise that students are central to the work of LA, we conclude by exploring the level of student awareness in relation to LA and highlight the limited research currently available in this field.

\section{Reports and visualisations in LA}

The concept of using pictures to represent data is not new and has existed in one form or another for many centuries (Spence, 2005). Improvements in computing technology have greatly increased the use of data visualisation, making it possible to process vast amounts of data at lightning-fast speeds; however, Few (2012) suggests that more widespread access to computing power has resulted in an increased number of poor visualisations. Today, data visualisation has become a rapidly evolving blend of science and art that is certain to change the way data is used and applied in everyday life, across a broad range of contexts (Knaflic, 2015). Bederson and Shneiderman (2003) suggest that the use of data visualisations can provide a clear overview of the context, the decisions that can be made and the potential implication of those decisions.

Reporting and visualisation of data is a frequent practice in the education sector with institutions accumulating vast amounts of transactional data from their activities to inform decisions, processes, progress and the business of education (Ferguson, 2012). More specifically, the widespread adoption of learning management systems (Cerezo, Sánchez-Santillán, Paule-Ruiz, \& Núñez, 2016) and other types of educational technologies (Gašević, Kovanović, \& Joksimović, 2017; Klašnja-Milićević, Ivanović \& Budimac, 2017) provides opportunities for data analysis and the creation of reports and visualisations to support the development of insights into learning data (Schwendimann et al., 2016). These visualisations have typically been presented as dashboards (Bodily \& Verbert, 2017), with charts and infographics representing various aspects of student learning. When visualisations are presented as dashboards, they include the provision of feedback on learning activities to teachers, students and administrators, as well as supporting reflection and decision-making, increasing engagement and motivation and maintaining student persistence.

The process of designing dashboards is frequently underpinned by user experience and participatory design methodology, that premise the active involvement of users in the decision-making processes (Sanoff, 2007). Despite the fact that student input in LA prototypes had been constrained to feedback on design or assessment of attitudes (Lohnes \& Kinzer, 2007; Seale, 2009), considerable insights into the expectations, motivations, skills and use cases of students has been achieved through this approach (Cole, 2009; Creanor, 
Trinder, Gowan, \& Howells, 2006). More recently evidence is emerging of students as co-designers of educational tools; this work is allowing developers to extend beyond what educators think will be useful to learners to the development of more authentic and personalised tools (de Quincey, Turner, Williams, \& Kyriacou, 2016; Vesin, Mangaroska, \& Giannakos, 2018).

\section{Lack of student perspectives}

To date, student involvement in the development and research surrounding LA in higher education has focused on student perceptions of the reporting systems and their usability (Bodily \& Verbert, 2017). There has been a distinct absence of the student perspective in decision-making regarding LA across the sector, and despite a body of work analysing student perceptions of particular systems and ethical considerations, little is known about how student attitudes may change across the student lifecycle or vary by disciplines of study or demographic groupings. It is also widely recognised that more research is necessary to examine student perspectives on LA and the perceived effects of these systems on student behaviour, achievement and skills (Marzouk et al., 2016; Roberts, Howell, Seaman \& Gibson, 2016).

Recent work conducted at a European university by Schumacher and Ifenthaler (2018) confirms that students generally hold a positive attitude towards LA. However, it is evident from the research of Roberts et al. (2016), students in the Australian context are unaware and unsure of what constitutes LA and, more importantly, lack awareness and understanding of the data that is being collected about them, who has access to that information and what universities could be using it for. Other Australian authors (Brooker, Corrin, Fisher, \& Mirriahi, 2017; Fisher, Valenzuela, \& Whale, 2014) have also noted this lack of awareness.

Despite the lack of student awareness about the scope of data and capability of LA, evidence suggests they are comfortable with the way the university collects their academic information (Brooker et al., 2017) and, when provided with additional information, readily identify functional links between the capability of LA and the potential impact on their learning (Ifenthaler \& Schumacher, 2016; Roberts et al., 2016; Schumacher and Ifenthaler, 2018). In the study by Ifenthaler and Schumacher (2016), students were presented with a number of dashboards of varying complexity to ascertain their preferences for and perceptions of the value of analytics systems. This work identified a directly proportional association between the complexity and breadth of data presented and student preference and positive perceptions. In a more recent study, Schumacher and Ifenthaler (2018) identified 15 potential features of LA that students saw as valuable to their learning, which included self-assessments; content recommendations; visual signals and graphs; suggestions for social interaction; and personalised learning activities (Ifenthaler \& Schumacher, 2016; Schumacher \& Ifenthaler, 2018).

In an alternative approach, the Learning Analytics Report Card project engaged students and their teachers to explore and critique the way in which LA data is produced and assessed to determine automated processes that may then be developed in relation to the data (Knox, 2017). Rather than collecting data from students in relation to their learning and then returning it to them in the form of reports, the Learning Analytics Report Card aimed to allow students "to 'play' with their data: to choose what is included or excluded, and when the report is generated", therefore giving them agency in what and how data is used and reported (Knox, 2017, p. 743).

The LA literature provides insight into student perceptions of both the positive and negative aspects of LA and also highlights a number of concerns. Positives included the potential value of analytics in creating a more personalised learning experience, tailored to support a particular individual's learning needs and approach and the capacity to make students feel like they are unique (Roberts et al., 2016). Additionally, students consider that LA could support stronger relationships between them and individual teachers/tutors and other students (Chen, Chang, Ouyang, \& Zhou, 2018; Roberts et al., 2016). Interestingly, students also identified the potential for analytical insights on student engagement with resources and learning materials to be an important source of data for subject improvement (Roberts et al., 2016).

Potential improvements in engagement, motivation and connection have also been identified as a positive outcome of the information from LA systems, particularly those that permit students to compare their progress to that of others (Atif, Bilgin, \& Richards, 2015; Corrin \& de Barba, 2014; Reimers \& Neovesky, 2015; Verbert et al., 2014). Such social framing is common in current analytics systems, though evidence 
also suggests that students hold the view that continuous comparison will foster a culture of competition over collaboration with the potential to redefine the norms of what constitutes successful learning (Jivet et al. 2017; Roberts, Chang, \& Gibson, 2017). As an extension of these concerns, students also considered the potential impact of comparison on confidence and emotional well-being, particularly for those that were making a significant effort, yet not achieving at a high standard. Similar concerns were raised in relation to the potential that students may misguidedly reduce their efforts where they are performing well (Roberts et al., 2017).

In addition to these concerns, evidence suggests that students consider the use of LA poses a potential risk to academic freedom, in so much as they will no longer have the ability to autonomously and anonymously negotiate their learning environment (Beattie, Woodley, \& Souter 2014; Roberts et al., 2016). In the focus groups conducted by Roberts et al. (2016), students expressed concern that they would no longer be treated as adults capable of self-regulating their learning and extrapolated this concern to consider the potential to impact their performance in the workplace. These discussions echo concerns raised by academics around the impact on student autonomy (Buckingham Shum \& Ferguson, 2012; Scott \& Nicols, 2017; Slade \& Prinsloo, 2013; West et al., 2015).

Students' perspectives are particularly important in relation to the development and use of student dashboards. However, in a comprehensive literature review, Bodily and Verbert (2017) analysed 93 articles exploring "click-level data and report this data directly to students" (p. 417). They discussed the importance of administering needs assessments to end users (students), yet only found six articles which described a needs analysis. In addition, these articles were concerned mainly with usability and usefulness, with only a small body of research examining students' perceptions of the impact of these systems on their learning. A study by Khan $(2017$, p. 270) found that students are cautious in that "they do not understand the technological complexity of learning analytics" and may need its meaning explained to them. However, those engaged in Khan's study were interested in identifying links between attendance and grades and saw the potential value in assessing "comprehensive data collection on learners' activities" (p. 269). They expressed a need for opportunities to opt out of data collection if they were not comfortable with its disclosure to some parties (including their teachers) and indicated the comparison of student data should only occur across relevant cohorts and contexts. The students also raised concerns around "wider sharing of their data and comparative analysis that may disengage learners with poorer achievement records" ( $p$. 270).

West et. al. (2015) identified the importance of placing students as central in both generating data and consuming outputs as work in relation to student dashboards progresses. Yet few discuss how they have determined what students want or how information on dashboards is accessed, interpreted and acted on by students. While attention to students as critical stakeholders is increasing, currently, as indicated by Schumacher and Ifenthaler (2018), there appears to be little alignment between the approaches and learning analytics. As indicated above, while practitioners discuss the importance of engaging with students, few identify ways to involve and/or empower them or more specifically invite them to have a say in the way data about their learning is collected, analysed and reported back to them (Jisc, 2018; Teasley \& Whitmer, n.d.). This lack of student involvement raises several issues related not only to relevance, but also the ethical and potentially legal implications.

According to Slade and Prisloo (2013), student participation is a recommended general ethical principle for decision-making regarding the use of big data and the development of LA in higher education. However, to enact this principle and collegially work with students, it is important to understand their attitudes towards the use of data, their understanding of the range of data collected and their concerns about its use. Tossell, Kortum, Shepard, Rahmati, and Zhong's (2015) exploration of student use of smartphones as an aid to study exemplifies the importance of capturing student perspectives. Their findings indicated students who had initially valued the opportunity to use smartphones for study purposes reported that in practice the phones served as "a distraction that deterred them from classroom goals" (p. 721). This study suggests that where student perspectives are sought they do not always provide the kinds of responses researchers and academics anticipate while demonstrating the significance of garnering and taking heed of students' perspectives as new approaches to teaching and learning are developed. As discussed earlier, researchers must also be aware, when working with students, they may not know or understand what the term learning analytics means or fully understand the implications of either LA or the data being collected. Students' lack of awareness of these issues can raise concerns in relation to the ethics of LA. 


\section{Ethical implications}

There are a variety of approaches to exploring the ethical issues surrounding LA. Many authors focus on privacy as an overriding concern (e.g., Gursoy, Inan, Nergiz, \& Saygin, 2017; National Academy of Education, 2017; Rubel \& Jones, 2016; Steiner, Kickmeier-Rust, \& Albert, 2016); however, exploration from non-legal perspectives highlights a much broader set of issues. For example, Johnson (2017, p. 77) argues for a structural justice approach which focuses on how LA's informational, operational and organisational structures "influence students' capacities for self-development and self-determination". Slade and Prinsloo (2013, p. 1510) advocate for a socio-critical perspective to bring to light the "role of power, the impact of surveillance, need for transparency and an acknowledgement that student identity is transient, temporal and context-bound construct." They argue that there are inherent power relations between students, institutions and other stakeholders (such as teachers and educational technology companies), which requires central surveillance to ensure ethical behaviour. Power is also highlighted by Buckingham Shum and Ferguson (2012) and Scott and Nicols (2017) in terms of the role that it plays in decision-making around what is being measured, who has access to the data and how data is being used. One would also suggest that, given the lack of student input, power is playing a role in the institutional decision-making related to the development (or not) of student-facing dashboards.

There are a range of uses for LA, including, most commonly, identifying at-risk students to assist in retention (examples include articles by Arnold \& Pistilli, 2012; Lawson, Beer, Rossi, Moore, \& Fleming, 2016; Prinsloo, Archer, Barnes, Chetty, \& van Zyl, 2015) and related to this, educational triage, where institutions utilise data to make decisions about where to best use limited resources (Prinsloo \& Slade, 2014). However, it can be used to serve learning (Booth, 2012; Slade \& Prinsloo, 2013); to personalise learning (Pardo \& Siemens, 2014); provide improved choices for students to respond faster to actionable insights (Oblinger, 2012; Prinsloo et al., 2015) and improve learning and teaching practice and curriculum (Bronnimann, West, Huijser, \& Heath, 2018; Prinsloo et al., 2015). However, there is also the potential for LA to be used for the inappropriate purpose - for example, selling of data, social sorting, reinforcing disadvantage, and digital stalking (Greller \& Drachsler, 2012). While we have more capability to ensure positive use, the greater danger is perhaps in unintended consequences (Johnson, 2017) or in techniques that mask various biases creating larger ethical issues.

In order to untangle some of these issues it is useful to draw on a range of perspectives to bring to light a fuller picture. Earlier work focused on what Greller and Drachsler (2012) see as a fundamental question: "who does a person's life data belong to?" (p. 50), which continues to be seen as one of the most controversial issues in the online and digital age (Pardo \& Siemens, 2014). This question is increasingly complex due to the type of data being collected, processed and analysed (Pardo \& Siemens, 2014). It continues to draw attention as our practices expand to various applications (Lawson et al., 2016). Although students are primary stakeholders and much of the data collected relates to them, they are not the only stakeholders, with teachers and institutions also contributing data. However, students are the most vulnerable group in this endeavour, as well as being the key stakeholders, and so should be the primary consideration in decision-making.

In focusing on students, the issue of privacy becomes increasingly difficult, as the combining of various data builds a more comprehensive picture of an individual which is both a strength and a weakness in LA. The combining of more sophisticated data sources such a biometric and locational data increasingly removes our ability to anonymise data (Greller and Drachsler, 2012). At the same time, such data combinations allow us to personalise the learning journey, which can be of great value to students. Johnson (2017) cautions that such personalisation can be a threat to autonomy (a key element in ethics) where LA applications can be paternalistic and disempower students (Buckingham Shum \& Ferguson, 2012; Johnson, 2017; Prinsloo \& Slade, 2016; Scholes, 2016). For example, recommender systems around courses or topics are designed to steer students in a particular direction based on the views of the institution, whereas Buckingham Shum and Ferguson (2012) argue that educational institutions have a particular view of success that not only drives our responses but also relates to the type of data we collect and use.

This is also connected to the issue of informed consent, raising questions related to the level of consent provided and the fullness of information we provide to students in order for them to make an informed decision. For example, a simple consent to utilise data collected in learning and teaching transactions masks the range of data that may be collected (e.g., locational data) and may not be clear about full range of 
purposes to which it is applied. Lawson et al. (2016) highlight the need to be clear about the purposes for which consent is provided and the need for institutions to remain vigilant about how data is used. They raise concerns about the ability of institutions to control the way consent is obtained and data is used, because it may be used in ways other than which it is intended, and academics may, in their interpretation of data, label students (Lawson et al., 2016).

These misuses of data (whether intentional or otherwise) may mean it is necessary to keep track of how LA is used. The issue of surveillance also has multiple facets. Surveillance can be seen as the need for central oversight (Lawson et al., 2016; Slade \& Prinsloo, 2013) so that monitoring takes place on how LA is being used by teachers, tutors and researchers to ensure it is not misused. However, Slade and Prinsloo (2013) also draw attention to the fact that people change behaviour when they know they are being watched (Bennett, 2018; Slade \& Prinsloo, 2013), which further impacts autonomy.

Complicating this picture further is the use of LA in research. Pardo and Siemens (2014, p. 443) argue that at the heart of definitions of LA "the objective of research initiatives in learning analytics is to provide techniques to understand and optimize learning and the environment in which it occurs." Considering LA in this way draws attention not just to the need to aggregate data for personalisation (impacting on anonymity) but also to the methods that are being used to do so, which are often not subjected to ethical frameworks. As Johnson (2017, p. 77) argues:

complexity also emerges because these challenges are often driven not by the kinds of choices about action usually addressed by professional ethics codes, but by beliefs about data science itself that hide the ethical choices in learning analytics behind a belief in technological neutrality and information objectivity.

Prinsloo (2017), drawing on the work of Watters (2016), suggests the need to ask the following critical questions to bring to light whose values are being used to guide the work: "Who benefits from algorithmic education technology? How? Whose values and interests are reflecting in its algorithms?" (p. 77).

Sitting behind such algorithms are the actual pieces of data and the way that these are classified and cleaned, which again can raise ethical issues and lead to unintended outcomes (Buckingham Shum \& Ferguson, 2012; Greller \& Drachsler, 2012; Slade \& Prinsloo, 2013). Data cleaning processes, which are often not transparent, can perpetuate current bias and prejudice, and privilege particular student groups (Johnson, 2017; Lawson et al., 2016). For example, Greller and Drachsler (2012) state that it may lead to a uniforming of the educational system in terms of both the students we take in but also the learning and teaching process while others echo similar concerns related to discrimination (Scholes, 2016).

Several authors (Prinsloo \& Slade, 2014; Slade \& Prinsloo, 2013) suggest the use of principles to guide our work. In terms of the principles which may assist, the usual values related to research, including autonomy, beneficence, non-maleficence and distributive justice, are useful but not sufficient. Other key values suggested by Pardo and Siemens (2014) to guide us include fostering trust, transparency and accountability. Applying these ideas to the range of literature suggests that transparency needs to be built into and applied at every stage of LA, including in relation to the type of information collected, stored and how the LA process is being carried out. It also implies accountability be applied at various levels, including an overall institution surveillance as well as local developer and user accountability. Additional suggestions for dealing with ethical issues includes having strong policies (Greller \& Drachsler, 2012), adherence to a code of practice for the sector (Pardo \& Siemens, 2014) and opening up the discussion across stakeholders, including students (Prinsloo, 2017). To date, and again, little work in this space has included the student perspective.

Finally, a perceived lack of privacy (Hoel \& Chen, 2016) and transparency has been identified as one of the most crucial factors impacting student acceptance of analytics systems in the higher education sector. The study by Ifenthaler and Schumacher (2016) explored the issue of privacy related to LA with 330 students. They found that while students had expectations related to personalised dashboards they also held fairly conservative views on sharing their personal information to contribute to these dashboards. Specifically, students were open to sharing data regarding their university studies and learning. However, they were reluctant to share their personal information, online behaviour (user path, download frequencies and online times) and social media engagement outside of the learning environment (Ifenthaler \& 
Schumacher, 2016) and wanted the opportunity to opt in and out of the dashboard (Roberts et al., 2016). This reluctance to share rich sources of information may limit the capabilities of analytics systems (Ifenthaler \& Widanapathirana, 2014); however, meeting the expectations of students regarding learning analytic functionality has the potential to increase the willingness of students to disclose the breadth of personal data required for valid prediction (Ifenthaler \& Schumacher, 2016; Scholes, 2016; Slade \& Prinsloo, 2013).

\section{Future directions - working toward a framework to include students' perspectives}

It is evident from the literature reviewed that although many authors in the field of LA see students as a key stakeholder group, there is scope for a range of work to identify students' perspectives regarding LA applications, visualisations and reports. To date, the reported research and development has largely been focused on teacher-centric or institutional approaches to or views of LA.

Development of student-facing dashboards appears to be limited. However, where they have been developed it seems (based on the literature) that this has been done most often without input from students, in terms of the types of dashboards they would like and the nature of the visualisation. Rather, the dashboards are often developed from the view of the academic or institution based on what we think would be useful for students, what we think we should provide or should be concerned about. So, although acknowledgement of the central role of students exists, our approach often remains paternalistic and reinforces subtle power imbalances. In summary, student perspectives have been largely absent from LA development and application. The lack of input from students regarding LA across these areas raises serious ethical concerns and suggests a need for several actions including most prominently engaging students. By doing so we would gain their insights as we explore LA and, as indicated earlier, it becomes both about and with' students, thus encouraging the co-creation of learning to occur (Dollinger \& Lodge, 2018).

Engaging students can take a variety of forms including strong empirical research which seeks students' views on their needs, concerns and how they feel their learning can be better supported with LA. Other forms of engagement may include user experience approaches to the development of user stories and principles to support the design of visualisations and dashboards. Additionally, this needs to be shared within the sector in order to develop a much more robust insight into the views of students to guide future development more broadly.

In response to this, the Innovative Research Universities (which includes seven Australian universities) is currently undertaking a survey of all course work students in our institutions with the intention of increasing our understanding of students' attitudes to and experiences of LA, and more specifically their understandings of and opinions regarding:

- the data the university collects about them and their concerns about its management

- how useful they believe a range of LA-driven interventions will be to their learning experience

- $\quad$ how they would best like their information displayed

- how they would like university data policies and practices communicated to them.

It is expected that this survey will provide much needed insight into students' awareness of and views on LA as well as providing guidance on the types of student-facing dashboards they would find useful. Further, it will support the development of a framework that can provide practical guidance to universities with regard to inclusion of students in the design and implementation of LA, by focusing on their relationship with LA.

\section{Acknowledgements}

The project team would like to acknowledge the Innovative Research Universities who are supporting this project. 


\section{References}

Arnold, K. E., \& Pistilli, M. D. (2012). Course signals at Purdue: Using learning analytics to increase student success. In S. Buckingham Shum, D. Gasevic, \& R. Ferguson (Eds.), Proceedings of LAK '12: 2nd International Conference on Learning Analytics and Knowledge (pp. 267-270). New York, NY: ACM. https://doi.org/10.1145/2330601.2330666

Atif, A., Bilgin, A., \& Richards, D. (2015). Student preferences and attitudes to the use of early alerts. In T. Bandyopadhyay, D. Beyene, \& S. Negash (Eds.), Proceedings of AMCIS 2015: Twenty-first Americas Conference on Information Systems (pp. 3410-3423). New York, NY: Curran Associates. Retrieved from http://aisel.aisnet.org/cgi/viewcontent.cgi?article=1297\&context=amcis2015

Beattie, S., Woodley, C., \& Souter, K. (2014). Creepy analytics and learner data rights. In B. Hegarty, J. McDonald, \& S.-K. Loke (Eds.), Critical perspectives on educational technology: Proceedings of ASCILITE 2014: 31st International Conference on Innovation, Practice and Research in the Use of Educational Technologies in Tertiary Education Conference (pp. 421-425). Dunedin, New Zealand: ASCILITE. Retrieved from http://ascilite.org/conferences/dunedin2014/proceedings/index.html

Bederson, B., \& Shneiderman, B. (2003). The craft of information visualization: Readings and reflections. San Francisco, CA: Morgan Kaufmann Publishers Inc.

Bennett, L. (2018). Students' responses to learning analytics dashboards: Research report. Huddersfield, UK: University of Huddersfield. Retrieved from https://www.srhe.ac.uk/downloads/reports2016/LizBennet-scoping2016.pdf

Bodily, R., \& Verbert, K. (2017). Review of research on student-facing learning analytics dashboards and educational recommender systems. IEEE Transactions on Learning Technologies, 10(4), 405-418. https://doi.org/10.1109/TLT.2017.2740172

Booth, M. (2012, July 18). Learning analytics: The new black. EDUCAUSE Review, 52-53. Retrieved from https://er.educause.edu/articles/2012/7/learning-analytics-the-new-black

Brooker, A., Corrin, L., Fisher, J., \& Mirriahi, N. (2017). Defining "data" in conversations with students about the ethical use of learning analytics. In H. Partridge, K. Davis, \& J. Thomas (Eds.), Proceedings of ASCILITE 2017: 34th International Conference on Innovation, Practice and Research in the Use of Educational Technologies in Tertiary Education (pp. 27-31). Toowoomba, Australia. ASCILITE. Retrieved from http://2017conference.ascilite.org/wp-content/uploads/2017/11/ConciseBROOKER.pdf

Bronnimann, J., West, D., Huijser, H., \& Heath, D. (2018). Applying learning analytics to the scholarship of teaching and learning. Innovation in Higher Education, 43(5), 353-367. https://doi.org/10.1007/s10755-018-9431-5

Buckingham Shum, S., \& Ferguson, R. (2012). Social learning analytics. Journal of Educational Technology \& Society, 15(3), 3-26. Retrieved from http://www.jstor.org/stable/jeductechsoci.15.3.3.

Cerezo R., Sánchez-Santillán M., Paule-Ruiz M. P., \& Núñez J. C. (2016). Students’ LMS interaction patterns and their relationship with achievement: A case study in higher education. Computers \& Education, 96, 42-54. https://doi.org/10.1016/j.compedu.2016.02.006

Chen, B., Chang, Y._H., Ouyang, F., \& Zhou, W. (2018). Fostering student engagement in online discussion through social learning analytics. The Internet and Higher Education, 37, 21-30. https://doi.org/10.1016/j.iheduc.2017.12.002

Cole, M. (2009). Using Wiki technology to support student engagement: lessons from the trenches. Computers \& Education, 52, 141-146. https://doi.org/10.1016/j.compedu.2008.07.003

Corrin, L., \& de Barba, P. (2014). Exploring students' interpretation of feedback delivered through learning analytics dashboards. In B. Hegarty, J. McDonald, \& S.-K. Loke (Eds.), Critical perspectives on educational technology: Proceedings of ASCILITE 2014: 31st International Conference on Innovation, Practice and Research in the Use of Educational Technologies in Tertiary Education Conference (pp. 629-633). Dunedin, New Zealand: ASCILITE. http://www.ascilite.org/conferences/dunedin2014/files/concisepapers/223-Corrin.pdf

Creanor, L., Trinder, K., Gowan, D., \& Howells, C. (2006) Who's learning and how? Researching the learner experience. In L. Markauskaite, P. Goodyear, \& P. Reimann (Eds.), Who's learning? Whose technology? Proceedings of the 23rd Annual ASCILITE Conference (pp. 179-188). Sydney, Australia: Sydney University Press. Retrieved from https://www.ascilite.org/conferences/sydney06/proceeding/pdf_papers/p93.pdf

de Quincey, E., Turner, M., Williams, N., \& Kyriacou, T. (2016). Learner analytics: The need for usercentred design in learning analytics. EAI Endorsed Transactions on Ambient Systems, 3(9), 1-4. https://doi.org/10.4108/eai.23-8-2016.151643 
Dollinger, M., \& Lodge, J. M. (2018). Co-creation strategies for learning analytics. In A. Pardo, K. Bartimote, G. Lynch, S. Buckingham Shum, R. Ferguson, A. Merceron, \& X. Ochoa (Eds.), LAK '18: Proceedings of the 8th International Conference on Learning Analytics and Knowledge (pp. 97-101). New York, NY: ACM. https://doi.org/10.1145/3170358.3170372

Ferguson, R. (2012). Learning analytics: Drivers, developments and challenges. International Journal of Technology Enhanced Learning, 4(5-6), 304-317. https://doi.org/10.1504/IJTEL.2012.051816

Few, S. (2012). Show me the numbers: Designing tables and graphs to enlighten. Burlingame, CA: Analytics Press.

Fisher, J., Valenzuela, F.-R., \& Whale, S. (2014). Learning analytics: A bottom-up approach to enhancing and evaluating students' online learning. Canberra, Australia: Australian Government Office for Learning and Teaching. Retrieved from https://hdl.handle.net/1959.11/15261

Gašević, D., Kovanovic, V., \& Joksimović, S. (2017). Piecing the learning analytics puzzle: A consolidated model of a field of research and practice. Learning: Research and Practice, 3(1), 63-78. https://doi.org/10.1080/23735082.2017.1286142

Greller, W., \& Drachsler, H. (2012). Translating learning into numbers: A generic framework for learning analytics. Educational Technology \& Society, 15(3), 42-57. Retrieved from https://www.jstor.org/stable/jeductechsoci.15.3.42

Gursoy, M. E., Inan, A., Nergiz, M. E., \& Saygin, Y. (2017). Privacy-preserving learning analytics: challenges and techniques. IEEE Transactions of Learning Technologies, 10(1), 68-81. https://doi.org/10.1109/TLT.2016.2607747

Hoel, T., \& Chen, W. (2016). Privacy-driven design of learning analytics applications: Exploring the design space of solutions for data sharing and interoperability. Journal of Learning Analytics, 3(1), 139-158. https://doi.org/10.18608/jla.2016.31.9

Ifenthaler, D., \& Schumacher, C. (2016). Student perceptions of privacy principles for learning analytics. Educational Technology Research and Development, 64(5), 923-938. https://doi.org/10.1007/s11423016-9477-y

Ifenthaler, D., \& Widanapathirana, C. (2014). Development and validation of a learning analytics framework: Two case studies using support vector machines. Technology, Knowledge and Learning, 19(12), 221-240. https://doi.org/10.1007/s10758-014-9226-4

Jisc. (2018, March 14). Learning analytics: Help or hindrance in the quest for better student mental wellbeing? Jisc: Inform feature. Retrieved from https://www.jisc.ac.uk/news/learning-analytics-helpor-hindrance-in-the-quest-for-better-student-mental-wellbeing

Jivet, I., Scheffel, M., Drachsler, H., \& Specht, M. (2017). Awareness is not enough: Pitfalls of learning analytics dashboards in the educational practice. In E. Lavoue, H. Drachsler, K. Verbert, J. Broisin, \& M. Perez-Sanagustin (Eds.), Data driven approaches in digital education: EC-TEL 2018: Proceedings of the 12th European Conference on Technology Enhanced Learning (pp. 82-96). Cham, Switzerland: Springer. https://doi.org/10.1007/978-3-319-66610-5 7

Jivet, I., Scheffel, M., Specht, M., \& Drachsler, H. (2018). License to evaluate: Preparing learning analytics dashboards for educational practice. In A. Pardo, K. Bartimote, G. Lynch, S. Buckingham Shum, R. Ferguson, A. Merceron, \& X. Ochoa (Eds.), LAK '18: Proceedings of 8th International Conference on Learning Analytics and Knowledge (pp. 31-40). New York, NY: ACM. https://doi.org/10.1145/3170358.3170421

Johnson, J. A. (2017). Ethics and justice in learning analytics. New Directions for Higher Education, 2017(179), 77-87. https://doi.org/10.1002/he.20245

Khan, O. (2017). Learners' and teachers' perceptions of learning analytics (LA): A case study of Southampton Solent University (SSU). In D. Sampson, J. M. Spector, D. Ifenthaler, \& P. Isaias (Eds.), Proceedings of the 14th International Conference on Cognition and Exploratory Learning in Digital Age (CELDA) (pp. 267-272). Setúbal, Portugal: IADIS Press. Retrieved from ERIC database (ED579477)

Kitto, K., Lupton, M., Davis, K., \& Waters, Z. (2016). Incorporating student-facing learning analytics into pedagogical practice. In S. Barker, S. Dawson, A. Pardo, \& C. Colvin (Eds.), Show me the learning: Proceedings of ASCILITE 2016 (pp. 338-347). Adelaide, Australia: ASCILITE. Retrieved from http://2016conference.ascilite.org/wp-content/uploads/ascilite2016_kitto_full.pdf

Kitto, K., Lupton, M., Davis, K., \& Waters, Z. (2017). Designing for student-facing learning analytics. Australasian Journal of Educational Technology, 33(5), 152-168. https://doi.org/10.14742/ajet.3607

Klašnja-Milićević, A., Ivanović, M., \& Budimac, Z. (2017). Data science in education: Big data and learning analytics. Computer Applications in Engineering Education, 25(6), 1066-1078.

https://doi.org/10.1002/cae.21844 
Knaflic, C. N. (2015). Storytelling with data: A data visualization guide for business professionals. New York, NY: John Wiley \& Sons.

Knox, J. (2017). Data power in education: Exploring critical awareness with the 'Learning Analytics Report Card'. Television \& New Media, 18(8), 734-752. https://doi.org/10.1177/1527476417690029

Lawson, C., Beer, C., Rossi, D., Moore, T., \& Fleming, J. (2016). Identification of 'at risk' students using learning analytics: The ethical dilemmas of intervention strategies in a higher education institution. Educational Technology Research and Development, 64(5), 957-968. https://doi.org/10.1007/s11423016-9459-0

Lohnes, S., \& Kinzer, C. (2007). Questioning assumptions about students' expectations for technology in college classrooms. Innovate: Journal of Online Education, 3(5), Retrieved from https://www.learntechlib.org/d/104341/

Long, P., \& Siemens, G. (2011). Penetrating the fog: Analytics in learning and education. Educause Review, 46(5), 31-40. Retrieved from https://er.educause.edu/ /media/files/articledownloads/erm1151.pdf $\% 20$

Marzouk, Z., Rakovic, M., Liaqat, A., J., Vytasek, J., Samadi, D., Stewart-Alonso, J., ... Nesbit. J. C. (2016). What if learning analytics were based on learning science? Australasian Journal of Educational Technology, 32(6), 1-18. https://doi.org/10.14742/ajet.3058

National Academy of Education. (2017). Big data in education: Balancing the benefits of educational research and student privacy: Workshop summary. Washington, DC: Author. Retrieved from ERIC database. (ED574440)

Oblinger, D. (2012, July 18). Let's talk analytics. Educause Review, 10-13. Retrieved from https://er.educause.edu/articles/2012/7/lets-talk--analytics

Pardo, A., \& Siemens, G. (2014). Ethical and privacy principles for learning analytics. British Journal of Educational Technology, 45(3), 438-450. https://doi.org/10.1111/bjet.12152

Prinsloo, P. (2017). Fleeing from Frankenstein's monster and meeting Kafka on the way: Algorithmic decision-making in higher education. eLearning and Digital Media, 14(3), 138-163. https://doi.org/10.1177/2042753017731355

Prinsloo, P., Archer, E., Barnes, G., Chetty, Y., \& van Zyl, D. (2015). Big(ger) data as better data in open distance learning. International Review of Research in Open and Distributed Learning, 16(1), 284306. https://doi.org/10.19173/irrodl.v16i1.1948

Prinsloo, P., \& Slade, S. (2014). Educational triage in open distance learning: Walking a moral tightrope. The International Review of Research in Open and Distance Education, 15(4), 307-331. https://doi.org/10.19173/irrodl.v15i4.1881

Prinsloo, P., \& Slade, S. (2016). Student vulnerability, agency, and learning analytics: An exploration. Journal of Learning Analytics, 3(1), 159-182. https://doi.org/10.18608/jla.2016.31.10

Reimers, G., \& Neovesky, A. Student focused dashboards: An analysis of current student dashboards and what students really want. In M. Helfert, M. T. Restivo, S. Zvacek, \& J. Uhomoibhi (Eds.), Proceedings of the 7th International Conference on Computer Supported Education (vol. 1, pp. 399-404). Setúbal, Portugal: CSEDU. https://doi.org/10.5220/0005475103990404

Roberts, L. D., Chang, V., \& Gibson, D. (2017). Ethical considerations in adopting a university- and system-wide approach to data and learning analytics. In B. Kei Daniel (Ed.), Big data and learning analytics in higher education (pp. 89-108). Cham, Switzerland: Springer.

Roberts, L. D., Howell, J. A., Seaman, K., \& Gibson, D. C. (2016). Student attitudes toward learning analytics in higher education: 'The Fitbit Version of the Learning World'. Frontiers in Psychology, 9(1959), 1-11. https://doi.org/10.3389/fpsyg.2016.01959

Rubel, A., \& Jones, K. M. (2016). Student privacy in learning analytics: An information perspective. The Information Society, 32(2), 143-159. https://doi.org/10.1080/01972243.2016.1130502

Sanoff, H. (2007). Special issue on participatory design. Design Studies, 28(3), 213-215. https://doi.org/10.1016/j.destud.2007.02.001

Scholes, V. (2016). The ethics of using learning analytics to categorise students on risk. Educational Technology Research and Development, 64(5), 939-955. https://doi.org/10.1007/s11423-016-9458-1

Schumacher, C., \& Ifenthaler, D. (2018). Features students really expect from learning analytics. Computers in Human Behavior, 78, 397-407. https://doi.org/10.1016/j.chb.2017.06.030

Schwendimann, B. A., Rodriguez-Triana, M. J., Vozniuk, A., Prieto Santos, L. P., Shirvani Boroujeni, M., Holzer, ... Dillenbourg, P. (2016). Understanding learning at a glance: An overview of learning dashboard studies. In Proceedings of the Sixth International Conference on Learning Analytics \& Knowledge (pp. 532-533). New York, NY, ACM. https://doi.org/10.1145/2883851.2883930 
Scott, J., \& Nichols, T.P. (2017). Learning analytics as assemblage: Criticality and contingency in online education. Research in Education, 98(1), 85-105. https://doi.org/10.1177/00345237/7723391

Seale, J. (2009). Doing student voice work in higher education: An exploration of the value of participatory methods. British Educational Research Journal, 36(6), 995-1015. https://doi.org/10.1080/01411920903342038

Slade, S., \& Prinsloo, P. (2013). Learning analytics: Ethical issues and dilemmas. American Behavioral Scientist, 57(10), 1509-1528. https://doi.org/10.1177/0002764213479366

Spence, I. (2005). No humble pie: The origins and usage of a statistical chart. Journal of Educational and Behavioral Statistics, 30(4), 353-368. https://doi.org/10.3102/10769986030004353

Steiner, C. M., Kickmeier-Rust, M. D., \& Albert, D. (2016). LEA in private: A privacy and data protection framework for a learning analytics toolbox. Journal of Learning Analytics, 3(1), 66-90. https://doi.org/10.18608/jla.2016.31.5

Teasley, S., \& Whitmer, J. (n.d.). The impact of student-facing LMS dashboards: Final report. Ann Arbor: University of Michigan. Retrieved from https://www.si.umich.edu/sites/default/files/REPORT\%20-\%20Student-Facing\%20Dashboards\%20\%20FinalHQ.pdf

Tossell, C. C., Kortum, P., Shepard, C., Rahmati, A., \& Zhong, L. (2015). You can lead a horse to water but you cannot make him learn: Smartphone use in higher education. British Journal of Educational Technology, 46(4), 713-724. https://doi.org/10.1111/bjet.12176

Verbert, K., Govaerts, S., Duval, E., Santos, J., Assche, F., Parra, G., \& Klerkx, J. (2014). Learning dashboards: An overview and future research opportunities. Personal and Ubiquitous Computing, 18(6), 1499-1514. https://doi.org/10.1007/s00779-013-0751-2

Vesin, B., Mangaroska, K., \& Giannakos, M. (2018). Learning in smart environments: User-centered design and analytics of an adaptive learning system. Smart Learning Environments, 5(1), 1-21. https://doi.org/10.1186/s40561-018-0071-0

West, D., Huijser, H., Lizzio, A., Toohey, D., Miles, C., Searle, B., \& Bronnimann, J. (2015). Learning Analytics: Assisting Universities with Student Retention. Sydney, Australia: Australian Office for Learning and Teaching. Retrieved from https://researchrepository.murdoch.edu.au/id/eprint/35134/

Corresponding author: Deborah West, deborah.west@,flinders.edu.au

Copyright: Articles published in the Australasian Journal of Educational Technology (AJET) are available under Creative Commons Attribution Non-Commercial No Derivatives Licence (CC BY-NC-ND 4.0). Authors retain copyright in their work and grant AJET right of first publication under CC BY-NC-ND 4.0.

Please cite as: West, D., Luzeckyj, A., Toohey, D., VAnderlie, J., \& Searle, B. (2020). Do academics and university administrators really know better? The ethics of positioning student perspectives in learning analytics. Australasian Journal of Educational Technology, 36(2), 60-70. https://doi.org/10.14742/ajet.4653 